\title{
Heat-stable serogroup-specific proteins of Yersinia pseudotuberculosis
}

\author{
V. A. Feodorova, J. G. Samelija and Z. L. Devdariani \\ Laboratory of Hybridomas, Russia State Antiplague Research Institute 'Microbe', Saratov, Russia
}

Correspondence

V. A. Feodorova

fedorova@mail.saratov.su

Received 16 July 2002

Accepted 10 January 2003

\begin{abstract}
A library of mAbs to the species- and serogroup-specific epitopes of Yersinia pseudotuberculosis serogroups I-VI was developed. These mAbs recognized linear sequential protein epitopes, as shown by ELISA and immunoblotting. Using the mAbs, Y. pseudotuberculosis was found to produce serogroup-specific proteins, whose synthesis was dependent on cultivation temperature. These proteins appeared to be parts of heat-stable O-antigens prepared by heating $Y$. pseudotuberculosis serogroups I- $\mathrm{VI}$ at $100^{\circ} \mathrm{C}$ for $2 \mathrm{~h}$, and are responsible for the protein serotype specificity of these bacteria. The high specificity of serogroup- or species-specific mAbs obtained in ELISA suggests that they may be effective for serotyping of $Y$. pseudotuberculosis strains or differentiation from other pathogenic yersiniae.
\end{abstract}

\section{INTRODUCTION}

Yersinia pseudotuberculosis is classified into serogroups on the basis of its somatic heat-stable (O-) antigen (Knapp \& Weber, 1982; Somov et al., 1990; Ovodov et al., 1992) or its endotoxin (Skurnik, 1999; Skurnik et al., 2000), which represents a complex of LPS with outer-membrane proteins (OMPs) (Solov'eva et al., 1990). The chemical structure and some immunobiological activities of LPSs, including the Oside chains of each Y. pseudotuberculosis serogroup or Osubgroup, have been studied (Knapp \& Weber, 1982; Somov et al., 1990; Ovodov et al., 1992; Skurnik, 1999). However, the role of proteins in the immunoreactivity of $\mathrm{O}$-antigens of $Y$. pseudotuberculosis is still not clearly defined. The immunological and structural diversity of protein antigens (OMPs, capsular antigens, $\mathrm{H}$ - or Vi-antigens, etc.) together with LPSs provides the basis for serological classification of the family Enterobacteriaceae (Frasch \& Gotschlich, 1974; Zollinger \& Mandrell, 1980; Ogasawara et al., 1985; Perry \& Fetherston, 1997; Pokrovsky \& Posdeev, 1999; Nandi et al., 2000; Feodorova et al., 2001). Y. pseudotuberculosis is able to produce some species-specific proteins (Ogasawara et al., 1985; Braithwaite et al., 1993; Aksenov et al., 1995; Nedashkovskaya et al., 1995; Burgasova et al., 1996; Drobkov et al., 1996; Kulyashova et al., 1997), but serogroup-specific proteins have not been reported.

In this study, several mAbs to serogroup- or species-specific protein epitopes of $Y$. pseudotuberculosis were characterized. The presence of heat-stable protein components in heatstable $\mathrm{O}$-antigens, bearing linear sequential epitopes complementary to serogroup-specific mAbs and providing serological specificity of $Y$. pseudotuberculosis, was shown.

Abbreviations: OMP, outer-membrane protein; $\mathrm{PK}$, proteinase $\mathrm{K}$.
The application of ELISA based on mAbs for serotyping of $Y$. pseudotuberculosis and its differentiation from other pathogenic yersiniae is discussed.

\section{METHODS}

Bacterial strains. Y. pseudotuberculosis strains used in this study are listed in Table 1. In addition, 24 strains of other bacteria (eight Yersinia pestis, six Yersinia enterocolitica, two Escherichia coli, three Proteus strains, three Shigella strains and two Salmonella strains) were employed. All the strains except $Y$. pestis were grown on Hottinger agar, $\mathrm{pH} 7 \cdot 2$, at $37^{\circ} \mathrm{C}$ for $48 \mathrm{~h}$, or at $28^{\circ} \mathrm{C}$ for $48 \mathrm{~h}$ for some experiments. $Y$. pestis strains were grown on Hottinger agar, $\mathrm{pH} 7 \cdot 2$, at $28{ }^{\circ} \mathrm{C}$ for $48 \mathrm{~h}$, or for some experiments at $28{ }^{\circ} \mathrm{C}$ for $24 \mathrm{~h}$ followed by $37^{\circ} \mathrm{C}$ for $24 \mathrm{~h}$.

Production and purification of mAbs. The conventional fusion procedure using PEG was used, with minor modifications (Galfre et al., 1977; Feodorova \& Devdariani, 2000). Briefly, to prepare sensitized spleen cells, female BALB/c mice, 6-10 weeks old and weighing 18-20 g, were given three intraperitoneal doses of sodium merthiolate-killed whole cells of $Y$. pseudotuberculosis serogroup II at 2-week intervals, according to the following schedule. The first injection contained $2 \times 10^{4}$ microbial cells emulsified in complete Freund's adjuvant (Sigma), the second contained $3 \times 10^{4}$ and the third, $6 \times 10^{4}$ microbial cells. After the final boost, the mice were killed by inhalation of ether. Spleens were collected aseptically from the mice and pressed through a sterile $5 \mathrm{ml}$ syringe into tissue culture medium, to produce a single-cell suspension. The cells were pelleted by centrifugation; erythrocytes were removed by hypotonic lysis with sterile $0.83 \% \mathrm{NH}_{4} \mathrm{Cl}$ in distilled water. The spleen cells were then fused with the $\mathrm{Sp} 2 / 0$-Ag14 BALB/c myeloma cell line (Feodorova \& Devdariani, 2000). Emerging clones were screened by ELISA. Selected hybridomas were cloned by limiting dilution and were grown in bulk. mAbs were purified by affinity chromatography as described previously (Feodorova \& Devdariani, 2000) and used in all experiments. The class and subclass of the mAbs were determined by immunodiffusion (Feodorova \& Devdariani, 2000) and found to be IgG1. 
Table 1. Y. pseudotuberculosis strains used in this study

\begin{tabular}{|c|c|c|}
\hline Strain & Description & Source \\
\hline CIP $55.85^{\mathrm{T}}$ & Serogroup I reference strain & CIP \\
\hline CIP 55.86 & Serogroup II reference strain & CIP \\
\hline CIP 55.87 & Serogroup III reference strain & CIP \\
\hline CIP 55.88 & Serogroup V reference strain & CIP \\
\hline CIP 55.89 & Serogroup IV reference strain & CIP \\
\hline 110 & Serogroup VI reference strain & IMC \\
\hline $603-73$ & Clinical isolate, Russia, 1973, serogroup I & IMC \\
\hline $10-\mathrm{B}$ & Clinical isolate, Russia, 1966, serogroup I & IMC \\
\hline $15-73$ & Clinical isolate, Russia, 1973, serogroup I & IMC \\
\hline 79 (212 Lucas) & Isolated in 1966 , serogroup I & HM \\
\hline $132-\mathrm{D}$ & Clinical isolate, Russia, 1967, serogroup I & IMC \\
\hline A17 & Clinical isolate, Russia, 1977, serogroup I & IMC \\
\hline $50-73$ & Clinical isolate, Russia, 1973, serogroup I & IMC \\
\hline $51(9)$ & Clinical isolate, Russia, 1963, serogroup I & IMC \\
\hline $\mathrm{U}-263$ & Clinical isolate, Russia, 1972, serogroup I & IMC \\
\hline $\mathrm{U}-267$ & Isolated from house rat, Russia, 1971, serogroup I & IMC \\
\hline U-272 & Isolated from house rat, Russia, 1971, serogroup I & IMC \\
\hline $220-73$ & Clinical isolate, Russia, 1973, serogroup I & IMC \\
\hline $596-73$ & Clinical isolate, Russia, 1973, serogroup I & IMC \\
\hline $603-73$ & Clinical isolate, Russia, 1973, serogroup I & IMC \\
\hline $611-73$ & Clinical isolate, Russia, 1973, serogroup I & IMC \\
\hline 54 & Isolated from house mouse, Russia, 1952, serogroup II & IMC \\
\hline 837 & Isolated in 1966, serogroup II & $\mathrm{HM}$ \\
\hline 854 & Isolated in 1966, serogroup II & HM \\
\hline 861 & Isolated in 1966 , serogroup II & HM \\
\hline 67 & Isolated in 1961, serogroup II & HM \\
\hline 55 & Isolated in 1971, serogroup II & IMC \\
\hline $445-73$ & Clinical isolate, Russia, 1973, serogroup III & IMC \\
\hline 162 & Isolated from Tamarisk gerbil, Russia, 1957, serogroup III & IMC \\
\hline $145-\mathrm{x}$ & Clinical isolate, Russia, 1971, serogroup III & IMC \\
\hline $445-73$ & Clinical isolate, Russia, 1973, serogroup III & IMC \\
\hline 677 & Isolated from Libyan jird, Russia, 1973, serogroup III & IMC \\
\hline 449-III-D & Clinical isolate, Russia, 1969, serogroup III & IMC \\
\hline 257 & Serogroup III & IMC \\
\hline 55 & Serogroup III & IMC \\
\hline 286 & Serogroup III & IMC \\
\hline 1500 & Serogroup III & IMC \\
\hline 53 & Isolated from house rat, Russia, 1961, serogroup IV & IMC \\
\hline 665-IV-D & Clinical isolate, Russia, 1965, serogroup IV & IMC \\
\hline 1421 & Isolated from house rat, Russia, 1962, serogroup IV & IMC \\
\hline $2255-71$ & Clinical isolate, Russia, 1971, serogroup IV & IMC \\
\hline 2098-71 & Clinical isolate, Russia, 1971, serogroup IV & IMC \\
\hline $\mathrm{U}-270$ & Isolated from mosquito, Russia, 1971, serogroup IV & IMC \\
\hline $\mathrm{U}-274$ & Isolated from house rat, Russia, 1972, serogroup IV & IMC \\
\hline U-275 & Isolated from house rat, Russia, 1972, serogroup IV & IMC \\
\hline $\mathrm{U}-276$ & Isolated from house rat, Russia, 1972, serogroup IV & IMC \\
\hline 810 & Received in 1966, serogroup V & $\mathrm{HM}$ \\
\hline $48518-\mathrm{V}$ & Clinical isolate, Russia, 1979 , serogroup V & IMC \\
\hline 70 & Isolated in 1961 , serogroup V & $\mathrm{HM}$ \\
\hline 56 & Isolated from common vole, Russia, 1954, serogroup V & IMC \\
\hline 2126 & Serogroup V & IMC \\
\hline 463 & Serogroup VI & IMC \\
\hline 1553 & Serogroup VI & IMC \\
\hline VI-J & Serogroup VI & IMC \\
\hline
\end{tabular}

${ }^{\star} \mathrm{CIP}$, Collection Institut Pasteur, Paris, France; HM, H. Mollaret (Institut Pasteur, Paris, France); IMC, Institute 'Microbe' Collection, Saratov, Russia. 
Antigens. To prepare the heat-stable O-antigens of $Y$. pseudotuberculosis serogroups I-VI, standard procedures were used (Knapp \& Weber, 1982; Somov et al., 1990). Briefly, broth cultures of each of the six serogroups were heated at $100{ }^{\circ} \mathrm{C}$ for $2 \mathrm{~h}$ and centrifuged at $2000 \mathrm{~g}$ for $15 \mathrm{~min}$. The pellets were washed twice with saline, resuspended in saline to a final density of $5.0 \times 10^{8}$ bacterial cells $\mathrm{ml}^{-1}$ and used for ELISA or SDS-PAGE.

ELISA. Several modifications of ELISA were used. Indirect ELISA was used for initial screening and after cloning, and for studying the ability of mAbs to recognize the $Y$. pseudotuberculosis serogroupspecific epitopes. ELISA plates (96-well) were sensitized with $100 \mu \mathrm{l}$ of a suspension containing $1 \times 10^{9}$ bacterial cells $(\mathrm{ml} \mathrm{PBS})^{-1}$, and incubated overnight at $4{ }^{\circ} \mathrm{C}$. The following bacterial strains were used: reference strains of $Y$. pseudotuberculosis serogroups I-VI, and 50 different $Y$. pseudotuberculosis strains (Table 1) or other closely related Gram-negative bacteria. The wells were washed three times with washing buffer (PBS containing $0.05 \%$ Tween 20). The wells were then saturated with $1 \%$ BSA in PBS for $1 \mathrm{~h}$ at $37^{\circ} \mathrm{C}$ and washed as above. Then, $100 \mu \mathrm{l}$ aliquots of cell culture supernates were added and the plates were reincubated for $1 \mathrm{~h}$ at $37^{\circ} \mathrm{C}$. After washing, peroxidase-labelled rabbit anti-mouse IgG (Gamaleya Institute, Russia) diluted in diluting buffer ( $1 \%$ BSA in PBS) was added and the plates were incubated for $1 \mathrm{~h}$ at $37^{\circ} \mathrm{C}$. The wells were washed six times. The substrate was $2,2^{\prime}$-azino-bis(3-ethylbenzthiazoline sulfonic acid) (Sigma) at $22.3 \mathrm{mg} \mathrm{ml}^{-1}$ in $0.05 \mathrm{mM}$ citrate buffer, $\mathrm{pH} 4 \cdot 0$, with $0 \cdot 0003 \% \mathrm{H}_{2} \mathrm{O}_{2}(100 \mu \mathrm{l})$. The $\mathrm{OD}_{405}$ was measured in a Titertek Multiscan spectrophotometer (Flow Laboratories). $\mathrm{An} \mathrm{OD}_{405}$ of $0 \cdot 2$ above the background level was considered to be a positive result. RPMI 1640 medium was used as a negative control.

Indirect double-antibody sandwich ELISA was used for studying the substrate specificity of the mAbs, i.e. their ability to react with protein or carbohydrate epitopes and to recognize conformational or linear epitopes of $Y$. pseudotuberculosis antigens. ELISA plates (96well) were sensitized with rabbit polyclonal absorbed IgG against $Y$. pseudotuberculosis serogroups I-VI (100 $\mu \mathrm{l}$ per well), purified by affinity chromatography as described previously (Feodorova \& Devdariani, 2000), at a protein concentration of $10 \mu \mathrm{g} \mathrm{ml}^{-1}$. Native, heated or proteinase K-treated (PK-treated) microbial cells of $Y$. pseudotuberculosis reference strains of the relevant serogroup $\left(1 \times 10^{9}\right.$ microbial cells $\mathrm{ml}^{-1}, 100 \mu \mathrm{l}$ per well $)$ were used as antigens. After incubation for $1 \mathrm{~h}$ at $37^{\circ} \mathrm{C}$ and washing, culture supernates containing mAbs were added. The remaining procedures were performed as described above.

SDS-PAGE and immunoblotting. Whole-cell lysates of $Y$. pseudotuberculosis serogroups I-VI $\left(5.0 \times 10^{8}\right.$ microbial cells per lane $)$ and heat-stable $\mathrm{O}$-antigens obtained from $Y$. pseudotuberculosis serogroups I-VI were subjected to SDS-PAGE according to Laemmli (1970), with a $4 \%$ stacking gel and $12.5 \%$ separating gel. For some experiments, the samples of heat-stable $\mathrm{O}$-antigens were incubated with SDS-PAGE sample buffer at $37^{\circ} \mathrm{C}$ instead of $100{ }^{\circ} \mathrm{C}$, according to Ogasawara et al. (1985). Electrophoresis was done at a constant current of $35 \mathrm{~mA}$ in Trisglycine buffer, $\mathrm{pH} 8 \cdot 3$, plus $0 \cdot 1 \%$ SDS buffer, for around $2 \cdot 5 \mathrm{~h}$. A set of low-molecular mass markers (Sigma) was used. The gels were counterstained with Coomassie brilliant blue R 250 (Sigma), $0.2 \%(\mathrm{w} / \mathrm{v})$ in $25 \%$ ethanol $(\mathrm{v} / \mathrm{v}), 7 \%$ acetic acid $(\mathrm{v} / \mathrm{v})$; for some experiments, gels were electrotransferred to nitrocellulose for Western blot analysis (Feodorova \& Devdariani, 2002). The membrane was incubated with the mAbs for $12 \mathrm{~h}$ at $4{ }^{\circ} \mathrm{C}$. Protein bands were detected with peroxidaselabelled anti-mouse IgG (Sigma).

\section{RESULTS}

\section{Characterization of mAbs}

After cloning, 19 stable hybridoma cell lines were selected. Two of them $\left(1 \mathrm{C}_{7}\right.$ and $\left.3 \mathrm{~B}_{3}\right)$ produced mAbs that were positive with the strains of two serogroups in indirect ELISA (Table 2). Fifteen hybridomas produced mAbs which only reacted strongly with the $Y$. pseudotuberculosis strains of the relevant serogroup. No cross-reaction with other pathogenic yersiniae was observed. Thus, these mAbs recognized serogroup-specific, but not strain-specific, epitopes of $Y$. pseudotuberculosis in ELISA. All the mAbs were directed to different serogroup-specific epitopes; this was confirmed by epitope analysis (data not shown). mAbs directed against three different serogroup-specific epitopes of $Y$. pseudotuberculosis serogroups I, III and VI, and against two different epitopes of serogroups II, IV and V, were obtained.

In addition, two hybridomas $\left(1 \mathrm{D}_{5}\right.$ and $\left.1 \mathrm{~F}_{3}\right)$ secreted mAbs that reacted with all $Y$. pseudotuberculosis strains of every serogroup used, independently of cultivation temperature, and gave no positive reaction with other bacteria. Both mAbs were directed to the same epitope and showed competition in epitope analysis (data not shown). Thus, mAbs directed to a single species-specific epitope of $Y$. pseudotuberculosis were obtained.

In indirect double-antibody sandwich ELISA, all the mAbs (except $3 \mathrm{~A}_{2}$ ) reacted with $Y$. pseudotuberculosis whole cells, but not with PK-treated ones. These mAbs recognized protein epitopes. $\mathrm{mAb} 3 \mathrm{~A}_{2}$ reacted with both native and PK-treated Y. pseudotuberculosis serogroup I, and recognized either a carbohydrate or a protein-carbohydrate epitope.

When tested in indirect double-antibody sandwich ELISA, all the mAbs reacted with both native and heated $Y$. pseudotuberculosis cells of the relevant serogroups. These $\mathrm{mAbs}$ were probably directed to linear sequential, but not conformational, epitopes located on heat-stable proteins of Y. pseudotuberculosis.

\section{Band patterns revealed by mAbs on immunoblotting}

In immunoblotting of each whole-cell lysate of $Y$. pseudotuberculosis serogroups I-VI with all the mAbs (except $\mathrm{mAb}$ $3 \mathrm{~A}_{2}$ ), a strong positive reaction was only seen with protein bands (Table 3 ). When the same PK-treated lysate was used, no positive reaction was observed. $\mathrm{mAb} 3 \mathrm{~A}_{2}$ gave strong positive immunoblotting with two peptides [molecular masses $41 \cdot 2\left(\mathrm{I}_{1}\right)$ and $38.0\left(\mathrm{I}_{2}\right) \mathrm{kDa}$ ] in a whole-cell lysate of $Y$. pseudotuberculosis serogroup I, and two carbohydrate components of molecular masses 38.0 and $19.0 \mathrm{kDa}$ in a PK-treated lysate.

\section{Identification of proteins recognized by mAbs in protein profiles of $Y$. pseudotuberculosis serogroups I-VI}

Fig. 1 (top) shows the profiles of $Y$. pseudotuberculosis 


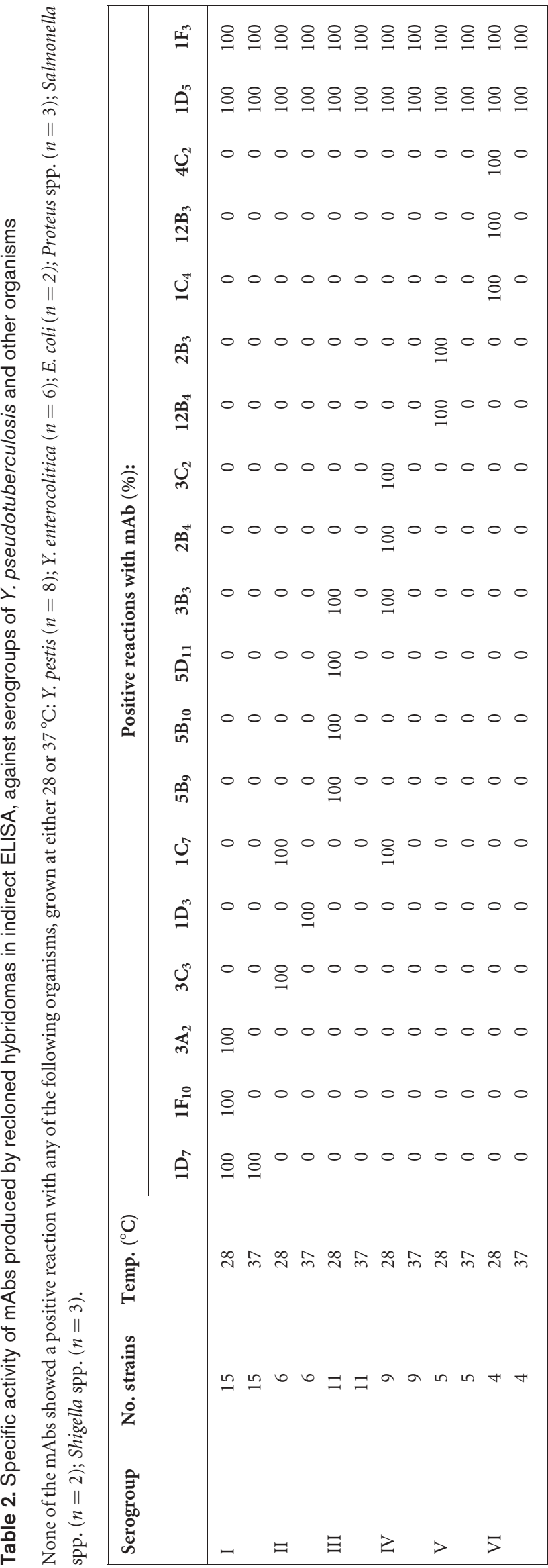

serogroups I-VI grown at $28^{\circ} \mathrm{C}$ (lanes $1-6$ ) or at $37^{\circ} \mathrm{C}$ (lanes 7-12). Slight cultivation temperature-dependent differences in protein profiles of the same strain were observed.

Proteins $\mathrm{I}_{1}$ and $\mathrm{III}_{3}$ were of similar molecular mass, were seen only in lysates of $Y$. pseudotuberculosis serogroups I and III grown at $28{ }^{\circ} \mathrm{C}$ (lanes 1 and 3), respectively, and were absent in all remaining strains. Protein $\mathrm{I}_{2}$ was of a molecular mass similar to those of $\mathrm{III}_{4}, \mathrm{IV}_{2}$ and $\mathrm{V}_{4}$, and was observed in all strains independently of cultivation temperature. In lysates of $Y$. pseudotuberculosis serogroups I, III and V, the abovementioned proteins were seen as major bands, while in lysates of $Y$. pseudotuberculosis serogroups II, IV and VI they appeared as minor bands. Protein $\mathrm{I}_{3}$ was seen only in $Y$. pseudotuberculosis serogroup I grown at $37^{\circ} \mathrm{C}$ (lane 7). Proteins $\mathrm{I}_{4}, \mathrm{I}_{5}$ and $\mathrm{I}_{6}$ had molecular masses identical to some proteins seen in lysates of $Y$. pseudotuberculosis serogroups IIII and VI grown at $28^{\circ} \mathrm{C}$; they were absent in lysates of other strains cultured at the same temperature.

The electrophoretic mobility of protein $\mathrm{II}_{1}$ was similar to that of $\mathrm{VI}_{3}$, which appeared only in lysates of $Y$. pseudotuberculosis serogroups II and VI independently of cultivation temperature. Protein $\mathrm{II}_{2}$ was seen in $Y$. pseudotuberculosis serogroup II grown at $28^{\circ} \mathrm{C}$ as a major band, while in the same strain grown at $37^{\circ} \mathrm{C}$, it appeared as a minor band (lanes 2 and 7, respectively). Protein $\mathrm{II}_{3}$ was observed only in Y. pseudotuberculosis serogroup II grown at $37^{\circ} \mathrm{C}$. Protein $\mathrm{II}_{4}$ had a molecular mass similar to that of proteins found in all $Y$. pseudotuberculosis serogroup I-VI strains grown at $28^{\circ} \mathrm{C}$.

Proteins $\mathrm{III}_{1}$ and $\mathrm{III}_{2}$ were seen only in Y. pseudotuberculosis serogroup III grown at $28{ }^{\circ} \mathrm{C}$. Proteins $\mathrm{IV}_{1}$ and $\mathrm{IV}_{3}$ were found only in $Y$. pseudotuberculosis serogroup IV grown at $28^{\circ} \mathrm{C}$. Proteins $V_{1}$ and $V_{2}$ possessed electrophoretic mobilities similar to those of proteins seen in Y.pseudotuberculosis serogroups I-VI independently of cultivation temperature, whereas $\mathrm{V}_{3}$ appeared only in $Y$. pseudotuberculosis serogroup $\mathrm{V}$ grown at $28^{\circ} \mathrm{C}$. Proteins $\mathrm{VI}_{1}$ and $\mathrm{VI}_{2}$ were seen only in $Y$. pseudotuberculosis serogroup VI grown at $28^{\circ} \mathrm{C}$.

\section{SDS-PAGE of Y. pseudotuberculosis serogroups I- VI O-antigens}

Fig. 1 (bottom) shows the protein profiles of heat-stable Oantigens obtained from $Y$. pseudotuberculosis serogroups IVI (samples were incubated with SDS-PAGE sample buffer at $100{ }^{\circ} \mathrm{C}$ ). Some of the proteins were denatured during the heating procedure and are observed as a diffuse background. One major protein band was found in Y. pseudotuberculosis lysates of each serogroup used, independently of cultivation temperature. This protein had a molecular mass of $38.0 \mathrm{kDa}$ in Y. pseudotuberculosis serogroups I, III, IV and V, or $40.0 \mathrm{kDa}$ in Y. pseudotuberculosis serogroups II and VI, which was similar to the molecular masses of $\mathrm{I}_{2}\left(\mathrm{III}_{4}, \mathrm{IV}_{2}\right.$ and $\left.\mathrm{V}_{4}\right)$ and $\mathrm{II}_{1}\left(\mathrm{VI}_{3}\right)$ found in whole-cell lysates of the same $Y$. pseudotuberculosis strains, respectively. In addition, most of the proteins recognized by the mAbs in immunoblotting were also seen by SDS-PAGE. 
Table 3. Reaction of mAbs in immunoblotting against $Y$. pseudotuberculosis serogroups I-VI

\begin{tabular}{|lcl|}
\hline $\mathbf{m A b}$ & Serogroup & \multicolumn{1}{c|}{ Protein bands in kDa (designation) } \\
\hline $1 \mathrm{D}_{7}$ & $\mathrm{I}$ & $38 \cdot 0\left(\mathrm{I}_{2}\right), 26 \cdot 0\left(\mathrm{I}_{3}\right)$ \\
$1 \mathrm{~F}_{10}$ & $\mathrm{I}$ & $58 \cdot 9\left(\mathrm{I}_{4}\right), 32 \cdot 7\left(\mathrm{I}_{5}\right), 78 \cdot 5\left(\mathrm{I}_{6}\right)$ \\
$3 \mathrm{C}_{3}$ & II & $40 \cdot 0\left(\mathrm{II}_{1}\right), 47 \cdot 3\left(\mathrm{II}_{2}\right)$ \\
$1 \mathrm{D}_{3}$ & II & $40 \cdot 0\left(\mathrm{II}_{1}\right), 29 \cdot 5\left(\mathrm{II}_{3}\right)$ \\
$1 \mathrm{C}_{7}$ & II, IV & $37 \cdot 7$ \\
$5 \mathrm{~B}_{9}, 5 \mathrm{~B}_{10}, 5 \mathrm{D}_{11}$ & III & $38 \cdot 0\left(\mathrm{III}_{4}\right)$ \\
$3 \mathrm{~B}_{3}$ & $\mathrm{III}, \mathrm{IV}$ & $40 \cdot 7\left(\mathrm{III}_{1}\right), 26 \cdot 0\left(\mathrm{III}_{2}\right) ; 39 \cdot 8\left(\mathrm{IV}_{1}\right), 38 \cdot 0 \pm 2\left(\mathrm{IV}_{2}\right)$ \\
$2 \mathrm{~B}_{4}, 3 \mathrm{C}_{2}$ & IV & $39 \cdot 8\left(\mathrm{IV}_{1}\right)$ \\
$12 \mathrm{~B}_{4}$ & V & $77 \cdot 6\left(\mathrm{~V}_{1}\right), 56 \cdot 9\left(\mathrm{~V}_{2}\right), 31 \cdot 3\left(\mathrm{~V}_{3}\right)$ \\
$2 \mathrm{~B}_{3}$ & V & $38 \cdot 0\left(\mathrm{~V}_{4}\right)$ \\
$1 \mathrm{C}_{4}$ & VI & $34 \cdot 7\left(\mathrm{VI}_{1}\right)$ \\
$12 \mathrm{~B}_{3}$ & VI & $31 \cdot 6\left(\mathrm{VI}_{2}\right)$ \\
$4 \mathrm{C}_{2}$ & VI & $40 \cdot 0\left(\mathrm{VI}_{3}\right)$ \\
$1 \mathrm{D}_{5}, 1 \mathrm{~F}_{3}$ & $\mathrm{I}, \mathrm{III}-\mathrm{V}$ & $38 \cdot 0$ \\
& II, VI & $40 \cdot 0$ \\
& & \\
\hline
\end{tabular}

The same samples were also subjected to SDS-PAGE when they were incubated with SDS-PAGE sample buffer at $37^{\circ} \mathrm{C}$ before analysis (Ogasawara et al., 1985). Although the same proteins could be seen in the profiles, their molecular masses were significantly lower than those found in the abovedescribed experiment.

\section{DISCUSSION}

In this study, a panel of species- or serogroup-specific mAbs to surface antigens of whole cells of $Y$. pseudotuberculosis was developed. Interestingly, immunochemical studies of the mAbs showed that all of them (except $3 \mathrm{~A}_{2}$ ) were directed to protein epitopes. This was revealed by (i) ELISA - all the mAbs reacted with $Y$. pseudotuberculosis whole cells but not with PK-digested ones; and (ii) immunoblotting - mAbs detected the complementary protein bands. This corresponds with the reported presence of several specific proteins in Y. pseudotuberculosis; for example, a $45 \mathrm{kDa}$ heat-stable toxin (Nedashkovskaya et al., 1995), a $103 \mathrm{kDa}$ protein encoded by the chromosomal inv gene (Kulyashova et al., 1997) and YopA (Aksenov et al., 1995). Moreover, when humoral response in patients with the generalized forms of pseudotuberculosis was studied, the antibody titres to OMPs were significantly higher than to other antigens, including LPS, in all periods of the disease (Burgasova et al., 1996). The same phenomenon was registered in experimental pseudotuberculosis in both mice and guinea pigs, after immunization of the animals with killed whole cells of $Y$. pseudotuberculosis (Drobkov et al., 1996). Specific proteins were also found in $Y$. pestis, which is closely related to $Y$. pseudotuberculosis (Perry \& Fetherston, 1997; Feodorova \& Devdariani, 2000). Further evidence that $Y$. pseudotuberculosis possessed specific proteins within each serogroup was obtained by examining the protein profiles of the reference strains of the six serogroups used in SDS-PAGE (Fig. 1, top).
In all cases, the proteins were observed to react with the relevant $\mathrm{mAb}$ in immunoblotting of the whole-cell lysates of the reference strains of a certain serogroup of $Y$. pseudotuberculosis. Moreover, the polypeptides were the protein components of heat-stable $\mathrm{O}$-antigens, bearing epitopes complementary to serogroup- or species-specific mAbs and providing the serological specificity of $Y$. pseudotuberculosis (Fig. 1, bottom). These data strongly suggest that proteins have a significant role in the serotyping of $Y$. pseudotuberculosis, as for some other Gram-negative bacteria (Zollinger \& Mandrell, 1980; Ogasawara et al., 1985; Perry \& Fetherston, 1997; Pokrovsky \& Posdeev, 1999; Nandi et al., 2000; Feodorova et al., 2001).

It is known that the expression of OMPs in yersiniae is temperature-regulated and associated with the presence of a virulence plasmid (Cornelis et al., 1998). In our study, all $Y$. pseudotuberculosis strains were cultivated in routine conditions in Hottinger agar without any ion supplements, which facilitate secretion of pLcr-encoded proteins (Cornelis et al., 1998). However, the SDS-PAGE profiles of Y. pseudotuberculosis strains grown at 28 or $37^{\circ} \mathrm{C}$ exhibited some differences (Fig. 1, top). Some proteins, e.g. $\mathrm{I}_{3}, \mathrm{II}_{3}, \mathrm{IV}_{3}$ and $\mathrm{VI}_{2}$, were found in the lysates independently of cultivation temperature and were probably temperature-independent proteins, while others were synthesized by $Y$. pseudotuberculosis strains at $28^{\circ} \mathrm{C}$ but not at $37^{\circ} \mathrm{C}$ (and vice versa) and appear to be temperature-regulated proteins. The changing ability of $Y$. pseudotuberculosis to synthesize some proteins depending on cultivation temperature was confirmed by ELISA. Most of the mAbs obtained gave strongly positive reactions with the strains grown at $28{ }^{\circ} \mathrm{C}$, and showed no reaction with the same strains grown at $37^{\circ} \mathrm{C}$ (Table 2). Thus, synthesis of $Y$. pseudotuberculosis serogroup-specific proteins is dependent on cultivation temperature. This phenomenon is not unique for $Y$. pseudotuberculosis and has been observed in other bacteria, for instance, Neisseria meningitidis (Zollinger \& 

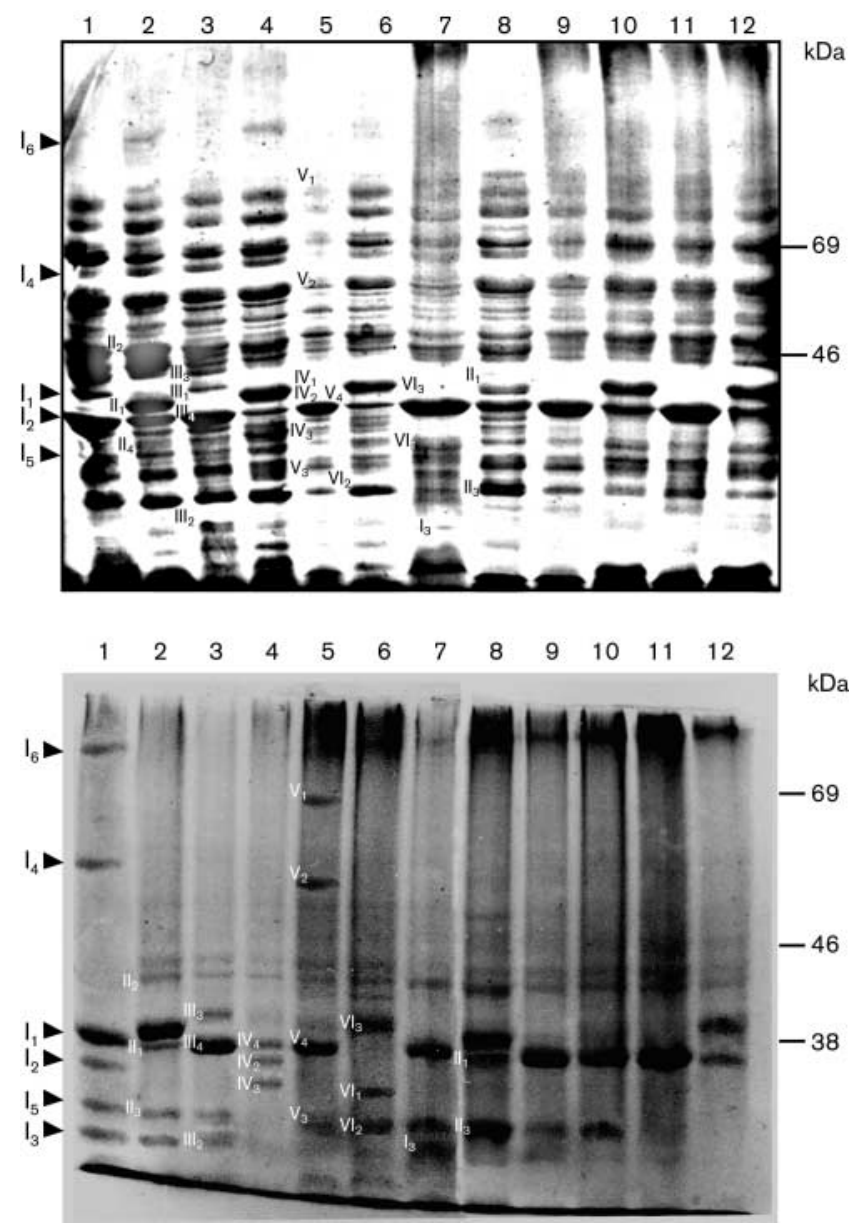

Fig. 1. SDS-PAGE of Y. pseudotuberculosis whole-cell lysates (top) and O-antigens (bottom) of serogroups I (lanes 1, 7), II (lanes 2, 8), III (lanes 3, 9), IV (lanes 4, 10), V (lanes 5, 11) and VI (lanes 6, 12), grown at $28^{\circ} \mathrm{C}$ (lanes $\left.1-6\right)$ or $37^{\circ} \mathrm{C}$ (lanes $7-12$ ).

Mandrell, 1977; Beher et al., 1984; Ogasawara et al., 1985). Y. pestis is also known to produce species-specific proteins (fraction I, fybrinolysin/coagulase and 'murine' toxin) which can be synthesized at cultivation temperatures of $37,28 / 37$ or $28 / 37^{\circ} \mathrm{C}$, respectively (Perry \& Fetherston, 1997; Feodorova \& Devdariani, 2000). In light of these results, correct serotyping of $Y$. pseudotuberculosis seems to be possible when optimal growth conditions are used.

One significant observation was that $Y$. pseudotuberculosis strains within each serogroup had multiple serogroupspecific epitopes revealed by using the mAbs. This could result from the presence of several different polypeptides with identical serological specificity, or multiple epitopes on the same polypeptide. Indeed, one protein reported previously as a porin (Novikova et al., 1996) or heat-modifiable OMP (Ogasawara et al., 1985) appeared to bear ten different serogroup- or species-specific epitopes. It was identified by alteration of its mobility when electrophoresed by SDSPAGE without or after heat treatment (Ogasawara et al., 1985). This protein was found in a number of members of the
Enterobacteriaceae, including all Yersinia species, and is responsible for protein type specificity in some bacteria due to the presence of multiple epitopes with different immunoreactivity (Knapp \& Weber, 1982; Novikova et al., 1996).

The remaining proteins recognized in immunoblotting by the mAbs were probably monomers of complicated mature protein molecules, bound by disulfide bonds and forming several epitopes with various specificities. This was confirmed by the results of immunoblotting of the mAbs with whole-cell lysates of $Y$. pseudotuberculosis electrophoresed without 2-mercaptoethanol. In all cases, mAbs detected a single complementary protein band (data not shown). All these data led us to conclude that $Y$. pseudotuberculosis is able to synthesize serogroup-specific proteins, consisting of one (in serovars I, III, IV, V and VI), two (in II) or three (in I and V) subunits, stabilized by disulfide bonds in the mature molecule, and in some cases forming several temperaturedependent epitopes with different specificities. Thus, $Y$. pseudotuberculosis can be classified on the basis of OMP antigens. Application of serogroup- and species-specific mAbs may prove useful for the development of highly sensitive, strictly specific and rapid ELISA diagnostic kits for serotyping of $Y$. pseudotuberculosis strains and their differentiation from other microbes, including pathogenic yersiniae.

\section{ACKNOWLEDGEMENTS}

This work was supported by the Russian Foundation for Basic Research (grants 01-04-48048 and 02-04-06637). We thank Dr N. Ye. Teryoshkina for help in preparing the manuscript.

\section{REFERENCES}

Aksenov, M. Y., Misurenko, E. N., Shustrova, N. M., Garovnikova, Yu. S., Gintsburg, A. L. \& Litvin, V. Yu. (1995). The detection and study of the dynamics of the count of nonculturable forms of Yersinia pseudotuberculosis in the environment by using the polymerase chain reaction. Zh Mikrobiol Epidemiol Immunobiol, 80-83 (in Russian).

Beher, M. G., Schnaitman, C. A. \& Pugsley, A. P. (1984). Major heatmodifiable outer membrane protein in gram-negative bacteria: comparison with the ompA protein of Escherichia coli. J Bacteriol 143, 906-913.

Braithwaite, C. E., Smith, E. E., Songer, J. G. \& Reine, A. H. (1993). Characterization of detergent-soluble proteins of Corynebacterium pseudotuberculosis. Vet Microbiol 38, 59-70.

Burgasova, O. A., Kuleshova, L. B., Tseneva, G. Ya., Yushchuk, N. D., Kukhtevich, E. V., Kuznetsov, V. F. \& Bondarenko, V. M. (1996). A comparative evaluation of different immunological reactions in the diagnosis of pseudotuberculosis. Zh Mikrobiol Epidemiol Immunobiol, 48-51 (in Russian).

Cornelis, G. R., Boland, A., Boyd, A. P., Geuijen, C., Iriarte, M., Neyt, C., Sory, M. P. \& Stainier, I. (1998). The virulence plasmid of Yersinia, an antihost genome. Microbiol Mol Biol Rev 62, 1315-1352.

Drobkov, V. I., Marakulin, I. V., Pogorelsky, I. P., Darmov, I. V. \& Smirnov, E. V. (1996). The antibody spectrum after the inoculation of sensitive animals with Yersinia pestis and Yersinia pseudotuberculosis bacteria. Zh Mikrobiol Epidemiol Immunobiol, 81-85 (in Russian). 
Feodorova, V. A. \& Devdariani, Z. L. (2000). Development, characterisation and diagnostic application of monoclonal antibodies against Yersinia pestis fibrinolysin and coagulase. J Med Microbiol 49, 261-269.

Feodorova, V. A., Gromova, O. V., Devdariani, Z. L., Dzhaparidze, M. N. \& Teryoshkina, N. Y. (2001). Immunochemical characterisation of Vibrio cholerae $\mathrm{O} 139 \mathrm{O}$ antigens and production of a diagnostic antiserum without absorption. J Med Microbiol 50, 499-508.

Frasch, C. E. \& Gotschlich, E. C. (1974). An outer membrane protein of Neisseria meningitidis group B responsible for serotype specificity. J Exp Med 140, 87-104.

Galfre, G., Howe, S. C., Milstein, C., Butcher, G. W. \& Howard, J. C. (1977). Antibodies to major histocompatibility antigens produced by hybrid cell lines. Nature 266, 550-552.

Knapp, W. \& Weber, A. (1982). Yersinia pseudotuberculosis. In Handbuch der bakteriellen Infectionen bei Tieren, vol. 4, pp. 466-518. Edited by H. Blobel \& T. Schliesser. Stuttgart: Gustav Fischer.

Kulyashova, L. B., Tseneva, G. Ya. \& Buinevich, Yu. B. (1997). The role of the outer-membrane antigens of Yersinia pseudotuberculosis in the pathogenesis and diagnosis of pseudotuberculosis. Zh Mikrobiol Epidemiol Immunobiol, 14-18 (in Russian).

Laemmli, U. K. (1970). Cleavage of structural proteins during the assembly of the head of bacteriophage T4. Nature 227, 680-685.

Nandi, B., Nandy, R. K., Mukhopadhyay, S., Nair, G. B., Shimada, T. \& Ghose, A. C. (2000). Rapid method for species-specific identification of Vibrio cholerae using primers targeted to the gene of outer membrane protein OmpW. J Clin Microbiol 38, 4145-4151.

Nedashkovskaya, E. P., Timchenko, N. F., Besednov, A. L. \& Vertiev, Yu. V. (1995). Thermostable Yersinia pseudotuberculosis toxin: its isolation, purification and the characteristics of its properties. $\mathrm{Zh}$ Mikrobiol Epidemiol Immunobiol, 5-9 (in Russian).

Novikova, O. D., Vostrikova, O. P., Portnyagina, O. Y., Khomenko, V. A., Solov'eva, T. F. \& Ovodov, Y. S. (1996). Antigenic properties of outer membrane porins in Yersinia genus. Biull Eksp Biol Med 121, 657-660 (in Russian).
Ogasawara, M., Kobayashi, S., Arai, S., Laheji, K., Hill, J. L., Kono, D. H. \& Yu, D. T. (1985). A heat-modifiable outer membrane protein carries an antigen specific for the species Yersinia enterocolitica and Yersinia pseudotuberculosis. J Immunol 135, 1430-1436.

Ovodov, Y. S., Gorshkova, R. P., Tomshich, S. V., Komandrova, N. A., Zubkov, V. A., Kalmykova, E. N. \& Isakov, V. V. (1992). Chemical and immunochemical studies on lipopolysaccharides of some Yersinia species. A review of some recent investigations. J Carbohydr Chem 11, 21-35.

Perry, R. D. \& Fetherston, J. D. (1997). Yersinia pestis - etiologic agent of plague. Clin Microbiol Rev 10, 35-66.

Pokrovsky, V. I. \& Posdeev, O. K. (1999). Medical Microbiology, pp. 21-145. Moscow: GEOTAR.

Skurnik, M. (1999). Molecular genetics of Yersinia lipopolysaccharide. In Genetics of Bacterial Polysaccharides, pp. 23-51. Edited by J. B. Goldberg. Boca Raton, FL: CRC Press.

Skurnik, M., Peippo, A. \& Ervela, E. (2000). Characterization of the Oantigen gene clusters of Yersinia pseudotuberculosis and the cryptic Oantigen gene cluster of Yersinia pestis shows that the plague bacillus is most closely related to and has evolved from Y. pseudotuberculosis serotype O:1b. Mol Microbiol 37, 316-330.

Solov'eva, T. F., Bakholdina, S. I., Yermak, I. M., Khomenko, V. A., Fedoreyeva, L. I., Novikova, O. D., Frolova, G. M., Likhatskaya, G. N. \& Ovodov, Yu. S. (1990). The protein moiety of endotoxin from Yersinia pseudotuberculosis: general characterization. Biorganic Chem 16, 1301-1309 (in Russian).

Somov, G. P., Pokrovsky, V. I. \& Besednova, N. N. (editors) (1990). Pseudotuberculosis, pp. 31-38. Moscow: Medicina.

Zollinger, W. D. \& Mandrell, R. E. (1977). Outer-membrane protein and lipopolysaccharide serotyping of Neisseria meningitidis by inhibition of a solid-phase radioimmunoassay. Infect Immun 18, 424-433.

Zollinger, W. D. \& Mandrell, R. E. (1980). Type-specific antigens of group A Neisseria meningitidis: lipopolysaccharide and heat-modifiable outer membrane proteins. Infect Immun 28, 451-458. 